\title{
Related Factors to the Use of Oral Health Services Amongst Population Aged 6 to 15 Years in Colombia
}

\author{
Factores Relacionados al Uso de Servicios de Salud Oral \\ en la Población de 6 a 15 Años en Colombia
}

Andrés A. Agudelo-Suárez*; Johan Sebastián Pérez-Escobar \& Eliana Martínez-Herrera**

AGUDELO-SUÁREZ, A. A.; PÉREZ-ESCOBAR, J. S. \& MARTíNEZ-HERRERA, E. Related factors to the use of oral health services amongst population aged 6 to 15 years in Colombia. Int. J. Odontostomat., 8(1):175-182, 2014.

ABSTRACT: The objective of this study was to analyze related factors to the use/no use of oral health services amongst children aged 6 to 15 in Colombia. Cross-sectional analysis with the information provided for the 2007 National Public Health Survey. Exposure variable: Use of oral health services. Health status variables: Self-rated health, oral health problems, oral pain, dental caries, gum bleeding. Explicative variables: Sex, age and ethnic origin. A descriptive study of the variables was carried out. Logistical regression was used to estimate the relationship between the category "never had an oral health visit" and each explicative and general and oral health status indicators, first crudely and after adjusting for other variables (Odds Ratio OR, 95\% Confidence Intervals 95\%Cl). Analyses were conducted separately for men (M) and Women (W). The prevalence of use of health services is higher in people reporting not to belong to an ethnic group, those reporting dental problems, oral-dental pain, dental caries and gum bleeding (statistically significant differences $p<0.05$ ). After adjusting for control variables people aged 6 to $8(\mathrm{~W}$ : OR $2.1895 \% \mathrm{Cl} 1.87-2.53)$, those reporting to belong to an ethnic group (M: 3.01 $95 \% \mathrm{Cl} 2.44-3.71 ; \mathrm{W}$ : OR $3.5995 \% \mathrm{Cl} 2.86-4.51)$ and those reporting poor self-rated health $(\mathrm{W}: \mathrm{OR} 1.4495 \% \mathrm{Cl} 1.25-1.66)$ were more likely to report "have never been to a dental visit". Inequalities in use of oral health services in Colombia amongst study population were found in younger children and those belonging to minority ethnic groups. These findings are linked to barriers to health services accessibility.

KEY WORDS: oral health, dental health services, health services accessibility, health inequalities.

\section{INTRODUCTION}

Access to oral health services has been considered an important topic concerning public health (Aday \& Andersen, 1974) because of its close relationship with health status of different social groups, especially those designated as vulnerable (Abadía Barrero, 2006). Although international strategies have been oriented to recommend the improvement of health services (Gilson et al., 2007), they have not taken into account sufficiently the necessity to guarantee equity in terms of age groups, ethnicity, sex, and social and economic conditions in case of oral health services. This situation causes a high burden of oral diseases in disadvantaged population groups increasing health inequalities and gaps in optimal results in oral health indicators (Petersen et al., 2005). Both oral and social epidemiology have shown an increasing interest for studying the oral profiles by means of analyzing the differences amongst age groups from a life cycle perspective (Sisson, 2007) and provided information about the role of different factors in the profile of use/ access of oral health services. Conversely, standard and global social politics propose a research and action agenda for children and adolescents (Rees et al., 2012), and research call for attention about the role of ineffective policies that could contribute to oral health care disparities (Fisher-Owens et al., 2008).

Scientific literature has shown the existence of differences in pattern of use of oral health services through the understanding the determinants that cause such inequalities. For instance, the $77 \%$ of children aged 0 to 6 in Brazil have never visited a dentist (Ba-

\footnotetext{
* Faculty of Dentistry. University of Antioquia, Medellín, Colombia.

${ }^{*}$ National School of Public Health. University of Antioquia, Medellín, Colombia.

SUPPORT: Ministry of Health and Social Protection (Colombia)-University of Antioquia (Reference: 519-2008).
} 
rros \& Bertoldi, 2002). The probability of receiving dental care was 5 times higher in children proceeding from high income families than those from low income. One study conducted in México (Medina-Solís et al., 2009) in children between aged 6 to 12, found economic and social predictors that influence the utilization of preventive and curative services such as economic position, type of insurance and education (public or private) and high and moderate oral health needs. A cross-sectional study conducted in 350 low-income families with children from 0 to 15 years living in Southern Brazil (Baldani et al., 2011), identified social and psychological inequalities in dental services utilization by means of a contextual model, recognizing a higher proportion of children who had never had a dental visit for reason of age, inadequate oral hygiene habits, lack of perceived need of dental care and whose families were under absent ownership.

Specifically, in Colombia, 3 national oral health studies were carried out in 1966, 1980 and 1998 (Mejía, 1971; Ministerio de Salud, 1998; Ministerio de Salud Instituto Nacional de Salud - ASCOFAME, 1980). Main findings point out the decrease of DMFT index (number of decayed, missing, and filled teeth) in scholar population according to the oral health goals of $\mathrm{WHO} /$ IDF. Nevertheless, inequalities have been observed when analyzed by socioeconomic status, educational level and type of insurance (Agudelo Suárez \& Martínez Herrera, 2009). Research about the profile of use of oral health services in specific social groups is limited, concretely in children and adolescents.

The 2007 National Public Health Survey (Encuesta Nacional de Salud Pública; ENSP-2007, in Spanish) provides an opportunity to observe the frequency of different variables related with the use of different health services and specifically those related with dentistry in Colombia (Ministerio de la Protección Social, 2007). Accordingly, this study aims to determine the prevalence of use of oral health services amongst children of 6 to 15 years in Colombia and further, to analyze contextual and individual related factors to the use/no use of those services.

\section{MATERIAL AND METHOD}

Design and setting. A national cross-sectional design was used. Data from the 2007 National Public Health Survey (Encuesta Nacional de Salud Pública, ENSP2007, in Spanish) were collected and a multiple-stage stratified sampling was used: the first-stage units were municipalities or the combination of one or more in the case of small towns; the second-stage units were blocks in case of urban regions and in census tracts in rural areas; and the third-stage units were family households. Within each household, one adult was selected to complete the survey (a key informant such as a head of household or and adult to enough knowledge of the information of all the members of the family). After the identification of all members, for all children between 6 and 17 years that belong to the household specific information was collected. Concretely, for this analysis, the information of 19,255 participants aged 6 to 15 was used. The research time allowed the use of this group for some international comparisons. Further research will be conducted in other age groups. Data were collected through face-to-face interviews at home between January and December 2007 (with exception of the Department of "San Andres y Providencia", which was collected between March and April 2008). For additional information, see the publication by the Ministry of Social Protection, Republic of Colombia (Ministerio de la Protección Social).

Study variables. The exposure variable was use of oral health services. This information was gathered from question 1352b of module 2 in the household survey: How long ago did you (last) visit a dentist or oral hygienist? The variable was re-categorized in three alternatives of dental visit: Never, time $>1$ year, time $\leq 1$ year.

To evaluate general and oral health status, several perceived outcomes were used separately: 1) self-rated health (Question 1001: How would you rate your current health status?) was categorized as good (good/very good) or poor (fair/poor/very poor); 2) Any oral health problem (Question 1317a: Have you had any dental, oral, and gum problem in the last 30 days? Yes/No); 3) Oral pain (Yes/No); 4) Dental caries (Yes/No); 5) Gum bleeding (Yes/No).

Other explicative variables were included in the analysis: Sex, age (6-8, 9-11 12-15), ethnic origin (This information was gathered from question 750: "What ethnic group do you belong to?" With 6 answer choices: Indigenous, Romani, Raizal, Palenquero, AfroColombian, and None). The variable was re-categorized in Yes/No.

Finally, the survey included some open questions about the reasons for the no use of oral health services. We categorized these variables in: 1) Structural access 
barriers (Yes/No): insurance problems, economic barriers, geographic barriers, opportunity in oral health care (opportunity in dental treatments, appointments), knowledge about health care rights; 2) Individual access barriers (Yes/No): Beliefs, Knowledge and attitudes about oral health (including cultural aspects), stress and anxiety.

Data analysis. Weights derived from a complex sample design were included. All the analyses were conducted to men (M) and women (W), separately (Kunkel \& Atchley, 1996). A descriptive study of the frequency of the variables analyzed was carried out. Prevalence of use of oral health services was measured for each category (Never, time $>1$ year, time $\leq 1$ year) according to explicative and general and oral health status indicators and Chi square test was used to observe statistical significant differences. The logistical regression was used to estimate the relationship between the category "never had an oral health visit" and each explicative and general and oral health status indicators, first crudely and then adjusting for other variables according to previous literature (Baldani et al.; Kunkel \& Atchley; Sisson). For these analyses, we used a model including all the confounders mentioned, and we show the complete adjusted models. Results were recorded as odds ratios (OR) with $95 \%$ confidence intervals $(95 \% \mathrm{Cl})$. Finally, barriers and determinants for non-use of oral health services (never) were identified through descriptive analysis. All calculations were computed using SPSS 18.0.

Ethical considerations. This paper is based on secondary analysis and the project was approved by an ethics committee. Data proceeded of the ENSP-2007 conducted by the Colombian Ministry of Social Protection (Ministerio de la Protección Social). This survey has accomplished the ethical requirements for human being research according to international standards and Colombian regulations.

\section{RESULTS}

Table I shows the distribution of the sample and the prevalence of use of oral health services amongst the target population included in the study. Gradients

Table I. Distribution of the sample and Prevalence of use of oral health services amongst population 6-15 years. Colombia, $2007(n=19255)^{*}$.

\begin{tabular}{|c|c|c|c|c|c|c|c|c|c|c|}
\hline \multirow{4}{*}{ Variables } & \multicolumn{5}{|c|}{ Men } & \multicolumn{5}{|c|}{ Women } \\
\hline & \multirow{3}{*}{ Sample (n) } & \multicolumn{4}{|c|}{ Oral health services visit } & \multirow{3}{*}{ Sample (n) } & \multicolumn{4}{|c|}{ Oral health services visit } \\
\hline & & \multirow{2}{*}{$\begin{array}{l}\text { Never } \\
\text { P (\%) }\end{array}$} & \multirow{2}{*}{$\begin{array}{c}>1 \text { year } \\
\mathrm{P}(\%)\end{array}$} & \multirow{2}{*}{$\begin{array}{l}\leq 1 \text { year } \\
\mathrm{P}(\%)\end{array}$} & \multirow{2}{*}{ p-value } & & \multirow{2}{*}{$\begin{array}{l}\text { Never } \\
\text { P (\%) }\end{array}$} & \multirow{2}{*}{$\begin{array}{c}>1 \text { year } \\
\text { P (\%) }\end{array}$} & \multirow{2}{*}{$\begin{array}{c}\leq 1 \text { year } \\
P(\%)\end{array}$} & \multirow{2}{*}{$p$-value } \\
\hline & & & & & & & & & & \\
\hline \multicolumn{11}{|l|}{ Age (years) } \\
\hline $6-8$ & 2866 & 17.5 & 25.0 & 57.5 & \multirow{3}{*}{$<0.001$} & 2613 & 18.4 & 24.9 & 56.7 & \multirow{3}{*}{$<0.001$} \\
\hline $9-11$ & 3062 & 14.1 & 31.3 & 54.5 & & 2673 & 12.8 & 29.7 & 57.4 & \\
\hline $12-15$ & 4078 & 13.7 & 40.2 & 46.1 & & 3962 & 10.7 & 36.3 & 53.0 & \\
\hline \multicolumn{11}{|l|}{ Ethnic group } \\
\hline No & 9416 & 14.1 & 33.0 & 52.9 & \multirow{2}{*}{$<0.001$} & 8680 & 12.7 & 31.0 & 56.3 & \multirow{2}{*}{$<0.001$} \\
\hline Yes & 590 & 27.9 & 35.6 & 36.5 & & 568 & 24.7 & 34.2 & 41.1 & \\
\hline \multicolumn{11}{|c|}{ Self-rated health } \\
\hline Good & 8041 & 14.1 & 33.7 & 52.2 & \multirow{2}{*}{$<0.001$} & 7373 & 12.5 & 31.5 & 55.9 & \multirow{2}{*}{$<0.001$} \\
\hline Poor & 1965 & 18.2 & 31.0 & 50.8 & & 1965 & 17.2 & 29.9 & 52.9 & \\
\hline \multicolumn{11}{|c|}{ Dental problems } \\
\hline No & 8860 & 15.5 & 34.6 & 49.9 & \multirow{2}{*}{$<0.001$} & 8024 & 14.0 & 32.9 & 53.1 & \multirow{2}{*}{$<0.001$} \\
\hline Yes & 1146 & 10.2 & 21.0 & 68.8 & & 1224 & 9.8 & 18.5 & 71.7 & \\
\hline \multicolumn{11}{|c|}{ Oral-dental pain } \\
\hline No & 9315 & 15.0 & 33.8 & 51.1 & \multirow{2}{*}{$<0.001$} & 8511 & 13.6 & 32.0 & 54.4 & \multirow{2}{*}{$<0.001$} \\
\hline Yes & 691 & 13.0 & 23.1 & 64.0 & & 737 & 12.2 & 20.8 & 66.9 & \\
\hline Dental caries & & & & & & & & & & \\
\hline No & 9602 & 15.0 & 33.6 & 51.5 & $<0001$ & 8851 & 13.5 & 31.7 & 54.8 & $<0001$ \\
\hline Yes & 404 & 12.8 & 22.6 & 64.6 & $<0.001$ & 397 & 12.6 & 17.6 & 69.8 & \\
\hline Gum bleeding & & & & & & & & & & \\
\hline No & 9757 & 14.9 & 33.3 & 51.8 & 0.258 & 8989 & 13.5 & 31.4 & 55.1 & $<0,01$ \\
\hline Yes & 249 & 13.8 & 28.6 & 57.6 & & 258 & 11.9 & 22.1 & 65.9 & \\
\hline Total & 10006 & 14.9 & 33.2 & 51.9 & & 9248 & 13.5 & 31.2 & 55.3 & \\
\hline
\end{tabular}

* Values are weighted. 
in the prevalence of use according to age were observed while the percentage of the use of oral health services in a period $\leq 1$ year and for never had an oral health services visit decrease for age for both sexes.

The prevalence of use of health services $(>1$ year, $\leq 1$ year) is higher in people reporting not to belong to an ethnic group, those to have dental problems, oral-dental pain, dental caries, and gum bleeding. Significant differences were found except in the case of gum bleeding for men.

Considering the logistic regression analyses (crude and adjusted) for never having had an oral health services visit according to different variables (Table II). Of the people aged 68 years (M: $1.4595 \% \mathrm{Cl} 1.27-$ 1.66; W: OR $2.1895 \% \mathrm{Cl} 1.87-$ 2.53), those reporting to belong to an ethnic group (M: 3.01 95\% Cl 2.44-3.71; W: OR 3.59 $95 \% \mathrm{Cl} 2.86-4.51$ ) and those reporting poor self-rated health (M: OR 1.30 95\%Cl 1.14-1.49; W: OR $1.4495 \% \mathrm{Cl} 1.25-1.66)$ were more likely to report "have never been to a dental visit". In case of oral health problems, people without health problems increase the answer probability of never had an oral services visit for both sexes. For other oral health indicators, statistically significant differences were not found. With respect to women, men were more likely to report, "have never been to a dental visit" (OR 1.12 95\% Cl 1.03-1.21).

The barriers to access and determinants for non-use of oral health services (never) amongst the target population according to different responses are

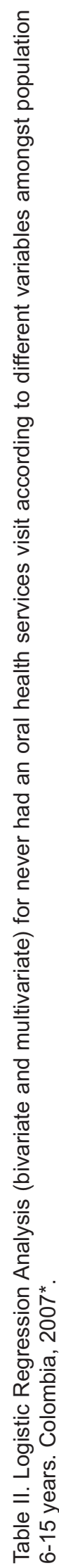




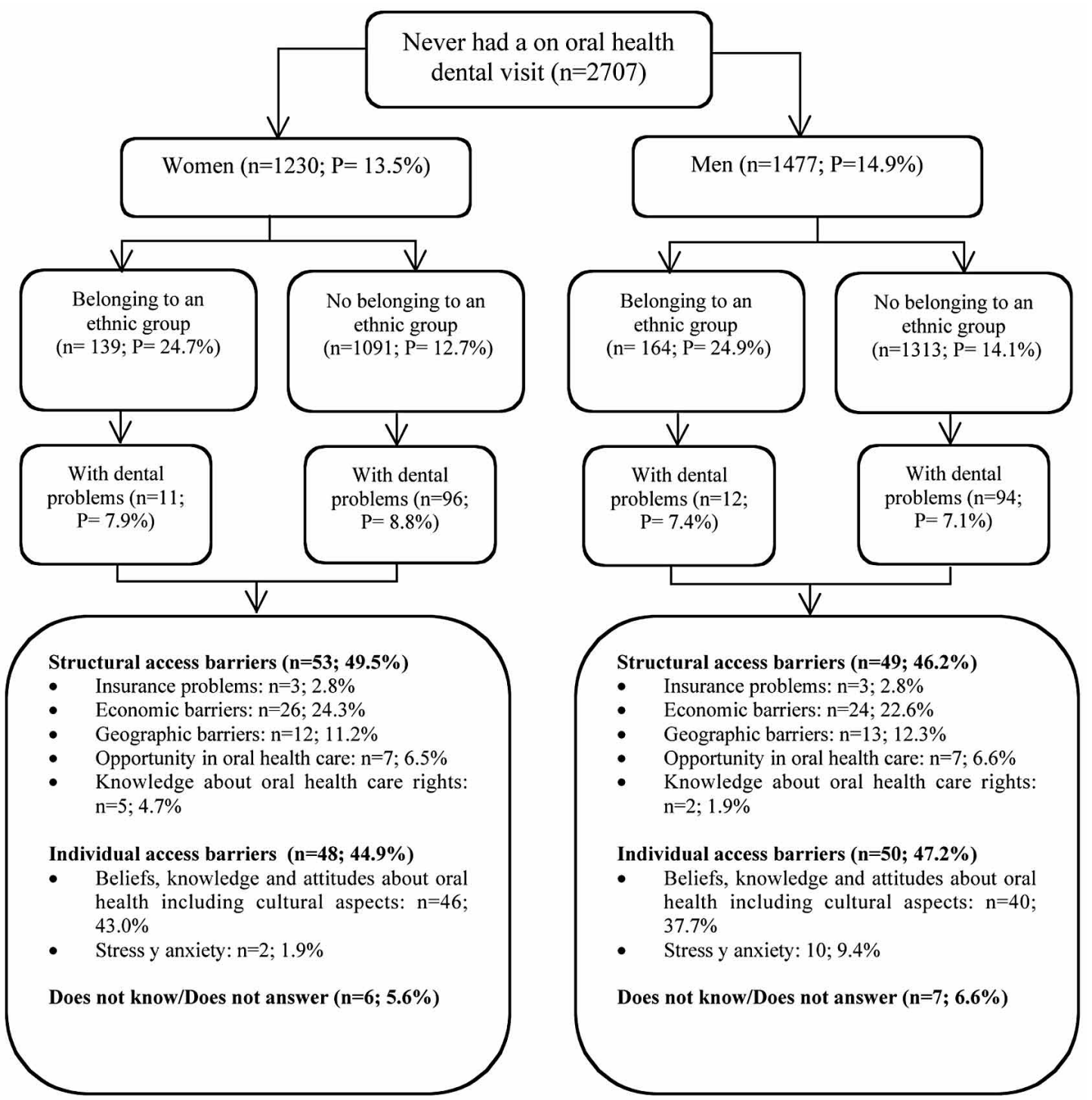

Fig. 1. Barriers and determinants of the no-use of oral health services (never) amongst population 6-15 years. Colombia, 2007*. *Values are weighted. $\mathrm{P}=$ Prevalence.

shown in Figure 1. Structural and individual barriers were found for men and women. Insurance problems, economic difficulties, geographic barriers, opportunity in oral health care, and a lack of knowledge of oral health care rights were the main structural barriers in contrast with individual barriers such as beliefs, knowledge and attitudes towards oral health including cultural aspects stress and anxiety.

\section{DISCUSSION}

Main results highlight inequalities in the accessibility to oral health services in children between 6 and 15 in Colombia. After adjusting for control variables, people aged $6-8$ years, those reporting to belong to a minority ethnic group and those reporting poor self-rated health were more likely to report "have never been to a dental visit".

The lower probability to received dental/oral health care has been described in the literature as "inverse dental care law" (Jones, 2001), which is an application of the named "inverse care law" by Hart (1971), meaning that those with the least need of health care use the health services more, and more effectively, than do those with greatest need. The absence of re- 
mediable differences in several aspects related with the use of oral health services is evident in demographically and geographically defined groups such as minority ethnic groups- is associated with inequities in health (Flores \& Tomany-Korman, 2008).

Literature has shown health inequalities in children from minority ethnic groups in comparison with other children. Research conducted in the U.S found that the percentage of children receiving medical and dental coverage or insurance is higher in comparison with the Latin and Afro-American counterparts (Flores \& Tomany-Korman). These disparities have been observed when analyzing optimal dental health, usual sources of care, medical and dental visits, unmet dental and medical needs, transportation barriers and, more precisely, in relationship with dental procedures (Bhagavatula et al., 2014). This situation seems to be unknown to priorities in public health since inequalities persists over time as has been demonstrated by followup studies (Flores \& Lin, 2013).

We found some correlation with answers given by children "have never been to a dental visit" mainly identified on structural barriers related with a lack of insurance in the Health Social Security System in Colombia. According to the Overall Performance Report by the World Health Organization (2000), which compares the National Health Systems, Colombia was in 22nd place in health system performance (World Health Organization). Important health reforms introduced in Colombia has increased the number of insured people to the system; nevertheless, this situation did not guarantee an equitable access to the different preventive and curative programs within the different levels of oral health care (Calderón et al., 2011).

Other important variables related with the utilization of oral health services reported by the respondents were geographic barriers that difficult the professional consultations and the opportunity in the dental treatment (Echavarría Acevedo, 2011). Also important individual factors such as beliefs, knowledge and attitudes regarding oral health including cultural aspects were considered (Baldani et al.; Franco Cortés et al., 2010). Literature has studied how cultural barriers to access to oral health services are related with the capacity of them to provide suitable professionals with cultural abilities to assist different social groups -e.g. minority ethnic groups- (Gao \& McGrath, 2011). There exist culturalization processes of the ethnic groups in general societies, which hinder proper integration and thus affect how oral health services are used (Gao \& McGrath). In some cases, this means feeling discriminated against by different institutions, unaccepted and misunderstood or perceiving a certain attitude towards them by health professionals (Jamieson et al., 2013). Lastly, individual factors related with stress and anxiety could on the one hand in some cases influence low utilization of health services, or on the other hand, could affect the behavior towards dental consultation, as seen in other studies (Chhabra et al., 2012).

Colombia is a country with special social and geographic characteristics. Approximately 6 million of people (14\% of the Colombian population) belong to different minority ethnic groups such as: Indigenous, Afro-descendants, Raizal, Palenquero and Rom or Romani (Departamento Administrativo Nacional de Estadística (DANE), 2005). Most of them are located in rural communities with important social problems and encountered many difficulties for moving to urban areas where primary oral health care centers are placed. Oral health loose priority is evident when seeking oral professional care only in cases of true dental/oral emergencies. Economic barriers (Calderón et al., 2011) are an important issue due firstly to the cost of commuting to the health center (in this case is associated to geographic barriers) and secondly to the need of payment for a percentage of total service (copayment). It is important to mention that an important part of the Colombian population live in poverty and indigence (Colombia Líder - Fedesarrollo, 2012).

The main focus of this study is the large sample size representing the whole country that constitutes the survey used in the analysis which gives value to the measures obtained which could be representative of the child population from 6 to 15 years of age in Colombia. The indicators studied were based on the interviewees' own perception of the utilization of health services and in the oral health indicators and individual understanding which is likely to vary depending on socio-demographic and other cultural factors. Selfperceived indicators constitute broad measures of health-related well-being transcending restrictive biomedical views of health and disease (Segovia et al., 1989). However, in interpreting the results, it is important to accept its limitations. First of all, the cross-sectional design of the study avoids assessing causality in the relationships observed. Prospective studies following diverse cohorts are needed to overcome these limitations. Because of the availability of data in the survey, results are limited to some health and sociodemographic variables and it is important to consider 
other important predictors and determinants that affect the use of oral health services. Finally, the interpretation of age in analysis could be problematic since children have their first dental visit at different ages, and logically, a higher percentage of children having a dental visit could increase with age. However, it is important to consider that pediatric dental visits should begin before 6 years and this situation does not occur frequently in oral health programs in Colombia.

Further research is needed to understand barriers faced by other age groups and incorporate new variables such as social class, occupation and type of insurance. This is well acknowledged and proposes new methodologies by means of multilevel analysis to explore the influence of contextual variables that affect the profile of utilization of oral health services. Qualitative research is flourishing in our context and offers new options to capture the subjective experience and individuals' perceptions of their own oral health in order to understand how determinants influence the access to health services and to identify causes for existing inequalities amongst different social groups.

The enactment of public policies, funding projects with public funds, updated censuses and programs, working with vulnerable populations, children and their caregivers, are tools that should be used and be constantly evaluated to reduce the gap in access to the populations most required services and avoid falling into an "inverse care law in oral health" where people who need the service are the ones with most restricted access.

AGUDELO-SUÁREZ, A. A.; PÉREZ-ESCOBAR, J. S. \& MARTíNEZ-HERRERA, E. Factores relacionados al uso de servicios de salud oral en la población de 6 a 15 años en Colombia. Int. J. Odontostomat., 8(1):175-182, 2014.

RESUMEN: El objetivo de este trabajo fue analizar los factores relacionados con el uso/no uso de los servicios de salud oral en población de 6 a 15 años en Colombia. Se realizó un estudio transversal con la información de la Encuesta Nacional de Salud Pública (2007). Variable de exposición: Uso de los servicios de salud oral. Variables de salud: indicadores de salud autopercibida (salud oral, general, dolor oro-facial, caries dental, sangrado de las encías). Variables explicativas: Sexo, edad y origen étnico. Descripción de las variables y análisis de asociación entre la categoría "nunca ha tenido una visita odontológica" y las variables explicativas y de salud; por medio de regresión logística calculando Odds Ratio crudas y ajustadas con sus intervalos de confianza al 95\% (OR-IC95\%). Se realizaron los análisis separadamente para hombres (H) y mujeres (M). La prevalencia de uso se servicios de salud oral es más alta en la población general, y los que reportan problemas de salud oral, dolor oro-facial, caries dental y sangrado de las encías (con diferencias estadísticamente significativas $p<0,05$ ). Después de ajustar por variables de control las personas de 6 a 8 años, (M: OR 2,18 IC95\%1,87-2,53), los que pertenecen a grupos étnicos minoritarios (H: 3,01 IC95\% 2,44-3,71; M: OR 3,59 IC95\% 2,86-4,51) y aquellos que reportan mala salud general (M: OR 1,44 IC95\% 1,25-1,66) tuvieron mayor probabilidad de referir que nunca habían tenido unavisita odontológica. Se encontraron desigualdades en el uso de los servicios de salud oral en Colombia en la población de estudio especialmente en los más jóvenes y aquellos que reportan pertenecer a grupos étnicos minoritarios. Estos hallazgos se relacionan con barreras de acceso a los servicios de salud.

PALABRAS CLAVE: salud oral, servicios de salud oral, accesibilidad a los servicios de salud.

\section{REFERENCES}

Abadía Barrero, C. E. Pobreza y desigualdades sociales: un debate obligatorio en salud. Acta Bioeth., 12(1):9-22, 2006.

Aday, L. A. \& Andersen, R. A framework for the study of access to medical care. Health Serv. Res., 9(3):208-20, 1974.

Agudelo Suárez, A. A. \& Martínez Herrera, E. La salud bucal colectiva y el contexto colombiano: un análisis crítico. Rev. Gerenc. Polit. Salud, 8(16):91-105, 2009.

Baldani, M. H.; Mendes, Y. B.; Lawder, J. A.; de Lara, A. P. ; Rodrigues, M. M. \& Antunes, J. L. Inequalities in dental services utilization among Brazilian low-income children: the role of individual determinants. J. Public Health Dent., 71(1):46-53, 2011.
Barros, A. J. \& Bertoldi, A. D. Desigualdades na utilização e no acesso a serviços odontológicos: uma avaliação em nível nacional. Ciênc. Saúde Colet., 7:709-17, 2002.

Bhagavatula, P.; Xiang, Q.; Eichmiller, F.; Szabo, A. \& Okunseri, C. Racial/ethnic disparities in provision of dental procedures to children enrolled in Delta Dental insurance in Milwaukee, Wisconsin. J. Public Health Dent., 74(1):50-6, 2014.

Calderón, C. A. A.; Botero, J. C.; Bolaños, J. O. \& Martínez, R. R. Sistema de salud en Colombia: 20 años de logros y problemas. Ciênc. Saúde Colet., 16:2817-28, 2011.

Chhabra, N.; Chhabra, A. \& Walia, G. Prevalence of dental anxiety and fear among five to ten year old children: a 
behaviour based cross sectional study. Minerva Stomatol., 61(3):83-9, 2012.

Colombia Líder - Fedesarrollo. Informe de pobreza 2012. Bogotá, Colombia Líder, 2012.

Departamento Administrativo Nacional de Estadística (DANE). Colombia. Una nación multicultural. Su diversidad étnica. Bogotá, Departamento Administrativo Nacional de Estadística (DANE), 2005.

Ministerio de la Protección Social. Encuesta Nacional de Salud Pública, Colombia. Bogotá, Ministerio de la Protección Social, 2007.

Echavarría Acevedo, N. Acceso a los servicios curativos de salud oral en escolares de la localidad de Fontibón de Bogotá D.C., 2009. Bogotá, Pontificia Universidad Javeriana, 2011.

Fisher-Owens, S. A.; Barker, J. C.; Adams, S.; Chung, L. H.; Gansky, S. A.; Hyde, S. \& Weintraub, J. A. Giving policy some teeth: routes to reducing disparities in oral health. Health Aff. (Millwood), 27(2):404-12, 2008.

Flores, G. \& Lin, H. Trends in racial/ethnic disparities in medical and oral health, access to care, and use of services in US children: has anything changed over the years? Int. J. Equity Health, 12:10, 2013.

Flores, G. \& Tomany-Korman, S. C. Racial and ethnic disparities in medical and dental health, access to care, and use of services in US children. Pediatrics, 121(2):e286-98, 2008.

Franco Cortés, A.; Ramírez Puerta, B.; Díaz Mosquera, P. \& Ochoa Acosta, E. VII monitoring: dental caries and oral health services access for school children in Medellín, 2009. Rev. Salud Pública de Medellín, 4:71-86, 2010.

Gao, X. L. \& McGrath, C. A review on the oral health impacts of acculturation. J. Immigr. Minor. Health, 13(2):202-13, 2011.

Gilson, L.; Doherty, J.; Loewenson, R.; Francis V \& on behalf of Commission of Social Determinants of Health-World Health Organization (WHO). Commission of Social Determinants of Health. Final Report Knowledge Network on Health Systems. Challenging inequity through health systems. Ottawa, Health Systems Knowledge Network Commission of Social Determinants of Health, World Health Organization (WHO), 2007.

Hart, J. T. The inverse care law. Lancet, 1(7696):405-12, 1971.

Jamieson, L. M.; Steffens, M. \& Paradies, Y. C. Associations between discrimination and dental visiting behaviours in an Aboriginal Australian birthcohort. Aust. N. Z. J. Public Health, 37(1):92-3, 2013.
Jones, C. M. Capitation registration and social deprivation in England. An inverse 'dental' care law? Br. Dent. J., 190(4):203-6, 2001.

Kunkel, S. R. \& Atchley, R. C. Why gender matters: being female is not the same as not being male. Am. J. Prev. Med., 12(5):294-6, 1996.

Medina-Solís, C. E.; Villalobos-Rodelo, J. J.; Márquez-Corona, M. L.; Vallejos-Sánchez, A. A.; Portillo-Núñez, C. L. \& Casanova-Rosado, A. J. Desigualdades socioeconómicas en la utilización de servicios de salud bucal: estudio en escolares mexicanos de 6 a 12 años de edad. Cad. Saúde Pública, 25(12):2621-31, 2009.

Mejía, R. On behalf of Ministerio de Salud. Morbilidad Oral. Investigación nacional de morbilidad. Estudio de recursos humanos para la salud y la educación médica en Colombia. Bogotá, Ministerio de Salud, ASCOFAME, 1971.

Ministerio de Salud. III Estudio Nacional de Salud Bucal ENSAB III, 1998. Bogotá, Ministerio de Salud, 1998.

Ministerio de Salud - Instituto Nacional de Salud -ASCOFAME. Morbilidad Oral. II Estudio Nacional. Bogotá, Ministerio de Salud- Instituto Nacional de Salud, 1980.

Petersen, P. E.; Bourgeois, D.; Ogawa, H.; Estupinan-Day, S. \& Ndiaye, C. The global burden of oral diseases and risks to oral health. Bull. World Health Organ., 83(9):661-9, 2005.

Rees, N.; Chai, J. \& Anthony, D. Right in Principle and in Practice: A Review of the Social and Economic Returns to Investing in Children. Social and economic policy working paper. New York, United Nations Children's Fund (UNICEF), 2012.

Segovia, J.; Bartlett, R. F. \& Edwards, A. C. An empirical analysis of the dimensions of health status measures. Soc. Sci. Med., 29(6):761-8, 1989.

Sisson, K. L. Theoretical explanations for social inequalities in oral health. Community Dent. Oral Epidemiol., 35(2):81-8, 2007.

World Health Organization (WHO). The World Health Report 2000. Health Systems: Improving performance. Geneva, World Health Organization, 2000.

Correspondence to:

Andrés A. Agudelo-Suárez

Department of Basic Studies

Faculty of Dentistry

University of Antioquia

C/ $64 N^{\circ}$ 52- 59 2nd Floor. Medellin

COLOMBIA

Received: 17-09-2013

Accepted: 18-02-2014

Email: oleduga@gmail.com 